\title{
IMPOSEX INDUCTION IN STRAMONITA HAEMASTOMA FLORIDANA (CONRAD, 1837) (MOLLUSCA: GASTROPODA: MURICIDAE) SUBMITTED TO AN ORGANOTIN-CONTAMINATED DIET
}

\author{
Aline Fernandes Alves de Lima ${ }^{1}$, Ítalo Braga de Castro $^{2 *}$ \& Cristina de Almeida Rocha-Barreira ${ }^{2}$ \\ ${ }^{1}$ Fundação Universidade de Rio Grande \\ Departamento de Ciências Fisiológicas - DCF \\ (Av. Itália, s/n - km 8, 96201-900 - Rio Grande, RS, Brasil) \\ ${ }^{2}$ Instituto de Ciências do Mar - Laboratório de Zoobentos \\ (Av. Abolição, 3207, Meireles 60165-081, Fortaleza, CE, Brasil) \\ *italo_braga@hotmail.com.br
}

\begin{abstract}
A B S T R A C T
Marine organisms are affected by organotin compounds due to the cumulative, deleterious effects of these latter. The most evident and well known consequence of organotin contamination is imposex, a hormonal disruption that causes a superimposition of sexual male features in females of prosobranchia neogastropod molluses such as Stramonita haemastoma floridana. Molluses accumulate organotins mainly because of their poor ability to eliminate TBT and DBT from their tissues. The aim of this study was to analyze organotin uptake by ingestion experimentally, using uncontaminated subjects (S. haemastoma floridana) fed with organotin-contaminated oysters (Crassostrea rhizophorae). A total of 248 gastropods, distributed in 7 tanks with uncontaminated water and contaminated food, were used in this study, a control group being fed uncontaminated oysters. Every 15 days, the individuals of one of the tanks were examined for the presence of imposex. Development of imposex was measured using the VDSI, RPSI and RPLI indexes. The animals had already developed imposex within the first 15 days, all the indexes measured (RPLI, RPSI and VDSI) having increased significantly with duration of exposure, indicating that the animals were probably contaminated by the food and had accumulated the pollutant. New paths of imposex development were also observed.
\end{abstract}

\section{RESUMO}

Organismos marinhos são afetados por compostos organoestânicos que causam uma série de efeitos deletérios aos mesmos. O mais conhecido efeito da contaminação por organoestânicos é o imposex. Esse fenômeno consiste na masculinização de fêmeas de moluscos neogastrópodes tais como Stramonita haemastoma floridana. Esses compostos tendem a se acumular em moluscos devido a sua baixa capacidade de eliminá-los. Um total de 248 indivíduos de $S$. haemastoma floridana foram coletados de uma população livre qualquer indício de imposex. Esses animais foram mantidos em 7 aquários, com aproximadamente 30 indivíduos cada, 1 desses aquários foi considerado como controle e os animas do mesmo alimentados com ostras obtidas de locais onde não se verificou a ocorrência de imposex em neogastrópodes nativos. Os animais nos outros 6 aquários foram alimentados com ostras obtidas em local onde a incidência de imposex entre os gastrópodes nativos revelou-se muito alta. A cada 15 dias, por um período total de 90 dias, os animais de um dos tanques eram retirados e analisados quanto à presença de imposex. Os níveis de imposex foram quantificados através da \% de imposex e dos índices: RPLI, RPSI e VDSI. Observou-se a indução de imposex em S. haemastoma floridana através da dieta a partir de Crassostrea rhizophora e um aumento significativo dos índices com o decorrer do tempo de exposição. Os animais do aquário controle foram analisados ao fim do experimento não revelando qualquer indício de imposex.

Descriptors: Imposex, Stramonita haemastoma, Induction, Diet, Organotin.

Descritores: Imposex, Stramonita haemastoma, Indução, Dieta, Organoestânicos.

\section{INTRODUCTION}

Various marine organisms are affected by organotin compounds, mainly because of their bioaccumulative, deleterious effects (Takahashi et al., 1997). TBT has chronic toxic effects at very low concentrations (1 to $3 \mathrm{ng} / \mathrm{L}$ ) (Takahashi et al., op. cit.). The main effect on neogastropod mollusks is the occurrence of imposex, an anomaly characterized by the induction of male sexual organs, such as penis and/or vas deferens, in female individuals. It is known that neogastropod mollusks such as Stramonita 
haemastoma develop imposex only when exposed in some way to organotin compounds (Matthiessen \& Gibbs, 1998).

In oysters, the main effect of such exposure is characterized by an abnormal formation of the shell, which grows exaggeratedly in overlapping calcium carbonate layers (Alzieu et al., 1982).

In filter-feeding bivalve mollusks, such as mytilids (Pelletier \& Normandeau, 1997), oysters (Granmo, 2000) and detritivorous mollusks, high bioaccumulation levels are to be expected because of the poor capacity of their tissues to degrade organotin compounds (Pelletier \& Normandeau, 1997). In bivalve mollusks, the main mechanism of contamination is the ingestion of phytoplankton, which also tends to accumulate TBT in large levels (Coelho et al., 2002).

Little is known about the accumulation (bioaccumulation) of ingested organotin compounds in marine organisms or their transfer through trophic chains (biomagnification). Takahashi et al. (1999) showed that some marine organisms, in different trophic chains, can accumulate organotin compounds to concentrations 70,000 times higher than that found in marine waters. However, they are not capable of any biomagnification, the concentration of these compounds being constant in the tissues of many species. Organotin compounds, unlike other pollutants, are biodegradable and have a low assimilative nature, and thus are not easily transferred through trophic chains. Takahashi et al. $(1997 ; 1998)$ found no correlation between organotin concentrations and the place of the species in the trophic chain either.

Having this in sight, the simple fact that bivalve and gastropod mollusks accumulate these compounds raises the question as to whether uncontaminated organisms, such as S.haemastoma floridana, may absorb and even accumulate organotin compounds in their tissues when fed a diet based on oysters contaminated with these compounds. This study sought to assess how far the exposure of S.haemastoma floridana to organotin compounds through their diet can induce the occurrence of imposex in this particular species.

\section{Materials And Methods}

First, an imposex-free population of $S$. haemastoma floridana was identified. A total of 248 individuals were sampled in July 2004 on the Caponga beach, State of Ceara, Brazil. The sampling was carried out manually in the intertidal strip, the animals placed in plastic recipients and brought to the laboratory.

Before the experiment, the imposex-free subjects remained in the laboratory and were fed on oysters (Crassostrea rhizophorae) harvested at the
Caça e Pesca beach, State of Ceara. Previous studies by Castro et al. (2000) had shown the absence of imposex in gastropod populations in that particular area, a fact suggesting that no organotin pollution exists there.

Seven aquaria were each filled with 10 litres of sea water from the Caponga beach, and approximately 30 individuals were transplanted into each of them. Six of the seven aquaria received oysters (Crassostrea rhizophorae) sampled at the marina of a shipyard and then presumably contaminated with organotins, since in these areas the occurrence of imposex in muricids is very common, due to ship maintenance, repair and construction operations performed at these installations. The seventh aquarium was used for the control group, whose gastropods were fed uncontaminated oysters harvested at the Caça e Pesca beach. In the aquaria, oysters were offered on a daily basis, and the water changed weekly.

Every 15 days, over a total of 90 days, the individuals of one of the aquaria were removed for testing. During this step, the animals were sedated with magnesium chloride $3.5 \%$ (Huet et al., 1995). The total length of the shells was measured, from the siphon channel to the spiral tip, using a calliper calibrated to $0.05 \mathrm{~mm}$. The shells were then removed using a mechanical lathe in order to examine the animals` soft tissues.

Gender was determined by the presence of a seminal receptacle in females and a prostate in males. Individuals presenting both a seminal receptacle and a penis were considered to be females with a certain degree of imposex.

The males penises were measured with a scaled sheet ( $1 \mathrm{~mm}$ scale). Females were examined for the occurrence of imposex using a magnifying glass.

Four different indexes were used to quantify the level of imposex, namely VDSI, RPLI, RPSI and the percentage of imposex.

The VDSI (vas deferens development index), initially proposed by Gibbs et al. (1987) and modified by Fernandez et al. (2002 and 2005), consists of the verification of the level of imposex development in each individual sampled. These levels were classified according to the following stages: 1) beginning of penile formation (papilla); 2) small penis already formed and beginning of formation of the penile duct; 3 ) female penis $<1 / 2$ the average length of a male penis at the same sampling station with. incomplete vas deferens ; 4) female penis $>1 / 2$ the average length of a male penis at the same sampling station with, complete vas deferens; 5) total blocking of the vulva; 6) abortive capsules.

The RPLI is obtained by this equation: (mean penis length in females / mean penis length in males) x 100 (Gibbs \& Bryan, 1987) been more appropriately used during the initial stages of imposex 
(Fernandez et al., 2002), and the RPSI by: (mean penis length in females) ${ }^{3} /$ (mean penis length in males) $^{3} \mathrm{x}$ 100 (Gibbs \& Bryan, 1987), being used for animals with advanced imposex stages (Fernandez et al., 2002). These indexes provide numerical values indicating the levels of imposex development in the sample studied.

Average VDSI, RPLI and RPSI values for the size of the female penises were statistically tested by variance analysis, using the Statistica ${ }^{\circledR}$ software, version 5.0

\section{Results}

Already at the first examination, 15 days after the beginning of the experiment, it was possible to detect the initial stages of imposex development (VDSI 1) in some animals. In this sampling, the RPSI and RPLI values were low, with the animals showing VDSI stages between 0 and 1 . Thirty days often the beginning of the test, a significant increase in the percentage of animals with imposex was observed, with $100 \%$ of the animals being at VDSI stages 1 or 2. An increase in the RPLI and RPSI indexes was also observed.

From the third through the fifth samplings, corresponding to 45,60 and 75 days respectively, from the beginning of the experiment, the animals showed a substantial increase in the VDSI, RPSI and RPLI indexes, all of them being between 0 and 4 .
The last sample corresponding to day 90 , was examined together with the control group. At this stage, the animals showed, again, an increase in the levels of imposex (Fig. 1). VDSI values remained between 1 and 4, yet the RPLI and RPSI indexes rose due to the increase in the total size of the females penises. No morphological alterations, indicative of the development of imposex, were found in the subjects of the control group tested.

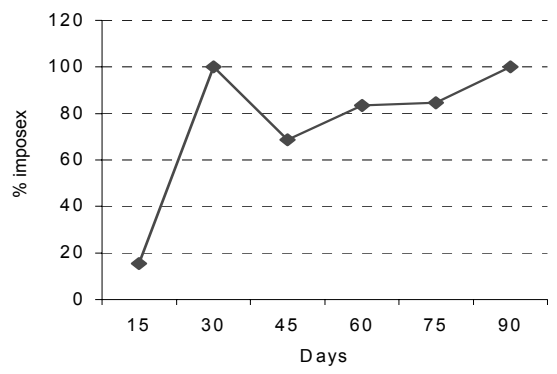

Fig. 1: Percentage of female S. haemastoma floridana, submitted to a diet of contaminated oysters for 90 days, with imposex.

The average size of the female penis increased significantly during the experiment $(\mathrm{p}<$ 0.005) (Fig. 2), a fact that affected the RPLI and RPSI levels, with large reduction occurring vary on the fifth sampling (day 75) (Fig. 3).

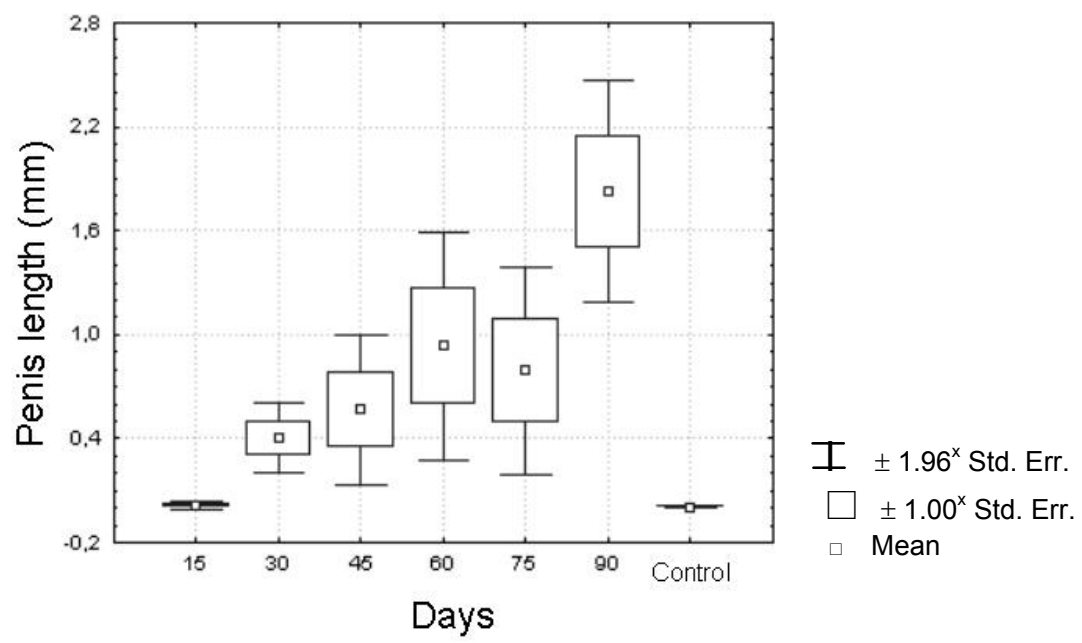

Fig. 2: Growth of the female penis in S. haemastoma floridana submitted to a diet of contaminated oysters. 


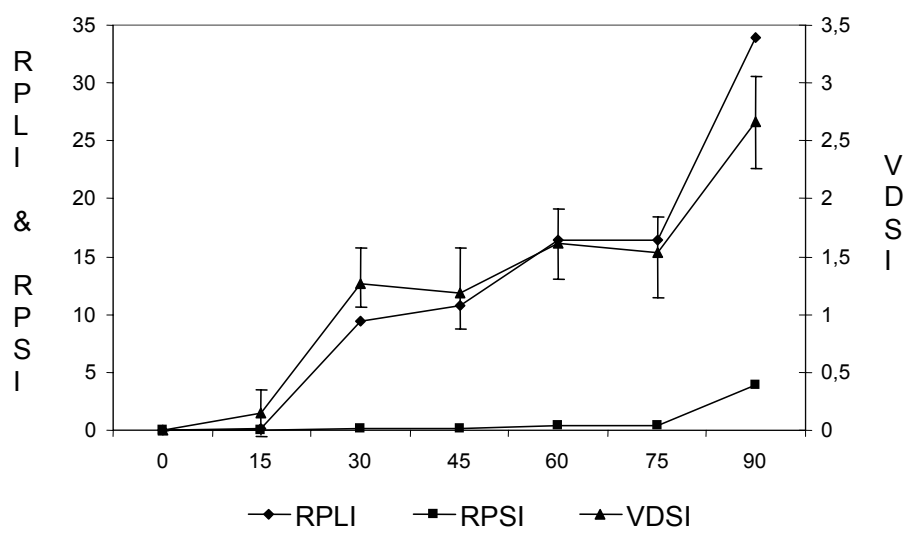

Fig. 3: Variations in the levels of RPSI, RPLI and VDSI observed in individuals of, $S$. haemastoma floridana submitted to a diet of contaminated oysters for the 90 days.

For the variation of the VDSI index, the average values of VDSI were taken into consideration, in accordance with Fernandez et al. (2002), corresponding approximately to the total VDSI value of the animals of each aquarium. We found an increase in the average VDSI at day 30 (mean VDSI $=1.27$ ), relative that one observed on day $15(0.15)$, and an even greater increase on day 90 (2.66).

Comparing the RPLI, RPSI and VDSI values, a gradual increase of all these indexes attronghont of the experiment was observed (Fig. 3).

During the experiment, some females showed morphological alterations different from those described in the existent imposex classification systems. Such alterations were considered to be alternative imposex developmental pathways, consisting in the occurrence of a papilla and a complete vas deferens, animals with a complete vas deferens and without a penis, and other individuals presenting a complete penis without any vas deferens at all.

\section{Discussion}

The capacity to accumulate organotin compounds, by both the oyster and the muricid, was already reported in different studies, with the appearance of a series of physical and physiological features (Pelletier \& Normandeau, 1997). As a general rule, bioaccumulation by ingestion of contaminated food depends on the product of the assimilative efficiency, metabolism and excretion or storage of the pollutant (Fisher \& Reinfelder, 1995; Coelho et al., 2002; Rudel, 2003).
One of the most accepted hypothesis explaining the occurrence of imposex is the inhibition of the P-450 aromatase, responsible for the conversion of androgen into estrogen (Morcillo \& Porte, 1998), thus inducing the appearance of male structures in female individuals.

It was possible to induce imposex in healthy S. haemastoma floridana individuals through a diet of oysters harvested in a region where the populations of this muricid showed high levels of imposex. Accordingly to Kure \& Depledge (1994), pollutants such as organotins are easily assimilated, since they are hydrophobic and can be accumulated in the lipidic reserves of the animal.

Although diet is of great importance in the absorption of organotin compounds, accumulation from waterborne concentrations is two orders of magnitude higher than that from thr ingestion of food (Coelho et al., 2002).

Imposex induction experiments, both in the laboratory and in the field, indicate that the VDSI and RPLI indexes are significantly correlated to the time of exposure, in various muricids (Bech et al., 2001), a fact corroborated by this study.

It is important to highlight that, since this study was performed under laboratory conditions, its results probably differ from those that would have been obtained in a natural environment, where other environmental variables may amplify or even reduce the effects caused by the exposure to organotin compounds, either by the ingestion of food or from the surrounding waters. Another fact to be taken into account is that contamination through water may increase the assimilative capacity of the animal. According to Coelho et al. (2002), environmental 
factors such as the relative TBT concentration in different locations and the relative abundance of available food, which often have an analogical relationship, different from that of an experiment carried out in a laboratory, are important as indicative of the assimilation paths of the pollutant.

Data obtained during this experiment also showed new imposex developmental pathways, different from those proposed by Fernandez et al. (2002) for Stramonita haemastoma. The occurrence of alternative imposex developmental paths was proposed by Stroben et al. (1995) for different prosobranchia species. Ribeiro-Ferreira (2002), while carrying out an imposex induction experiment with $S$. haemastoma on the coast of Rio de Janeiro, also observed the occurrence of different imposex developmental pathways.

Some aphalic animals were found in the samples examined. Aphalia is a genetic deficiency, known as the Dumpton syndrome, characterized by the absence of a male sexual feature, in which females exposed to organotin compounds develop only a vas deferens, as has already been observed in Nucella lapillus and Ocenebrina erinacea populations (Gibbs, 1993; Ohelmann et al., 1996; Ribeiro-Ferreira, 2002).

Ribeiro-Ferreira (2002) emphasized the need for an imposex scale specific to Stramonita haemastoma, after the significant occurrence of aphalic individuals in his induction experiment. However and also taking into account the observations made in contaminated areas, such alternative developmental paths were not frequent. Probably, such occurrences in both Ribeiro's and this present study were due to the acute exposure of the subjects to organotin compounds, which may have led to the disordered appearance of the morphological alterations typical of imposex.

\section{REFERENCES}

Alzieu, C.; Heral, M.; Thibaud, Y.; Dardignac, M. \& Feuillet, M. 1982. Influence des peintures antisalissures a base d'organostanniques sur la calcification de la coquille de l'huitre Crassostrea gigas. Rev. Trav. Inst. Péches Marit., 45:101-116.

Bech, M. 2002. Imposex and tributyltin contamination as a consequence of the establishment of a marina, and increasing yachting activities at Phuket Island, Thailand. Environ. Pollut., 117:421-429.

Castro, I. B.; Matthews-Cascon, H. \& Fernandez, M. A. S. 2000. Imposex em Thais haemastoma (Linnaeus, 1767) (Mollusca: Gastropoda) uma indicação da contaminação por organoestânicos na costa do município de Fortaleza. Arq. Ciênc. Mar.,Bras., 33:51-56.

Coelho, M. R.; Bebiano, M. J. \& Langston, W. J. 2002 Routes of TBT uptake in the clam Ruditapes decussatus. II. Food as vector of TBT uptake. Mar. environ. Res., 54:193-207.
Fernandez, M. A. S.; Limaverde, A. C.; Castro, I. B.; Wagener, A. L. R. \& Almeida, A. C. O. 2002. Occurrence of imposex in Thais haemastoma: possible evidence of environmental contamination derived from organotin compounds in Rio de Janeiro and Fortaleza, Brazil. Rep. Public Health.,18(2):463-476.

Fernandez, M. A. S.; Wagener, A. L. R.; Limaverde, A. C.; Scofield, A. L.; Pinheiro, F. M. \& Rodrigues, E. 2005. Imposex and surface sediment speciation: A combined approach to evaluate organotin contamination in Guanabara Bay,Rio de Janeiro, Brazil. Mar. environ. Res., 59:435-452.

Fisher, N. S. \& Reinfelder, J. R. 1995. The transfer of metals in marine systems. In: Tessier, A. \& Turner, D. R. eds. Metal speciation and bioavailability in aquatic systems. Chichester; John Wiley. 1995:363-406.

Gibbs, P. E. \& Bryan, G. M. 1987. TBT paints and demise of the dog-whelk Nucella lapillus (Gastropoda). J. mar. Biol. Ass. U.K., 68:1482-1487.

Gibbs, P. E.; Bryan, G. M.; Pascoe, P. L. \& Burt, G. R. 1987. The use of dog-whelk Nucella lapillus as an indicator of tributyltin (TBT) contamination. J. mar. biol. Ass. U.K., 67:507-523.

Gibbs, P. E. 1993. Phenotypic changes in the progeny of Nucella lapillus (Gastropoda) transplanted from an exposed shore to sheltered inlets. J. molluscan Stud., 59:187-194.

Granmo, A. 2000. Effects of organotin on marine bivalves. Phuket mar. biol. Cent., Spec. Publ., 21:127-132.

Huet, M.; Fioroni, P.; Oehlmann, J. \& Stroben, E. 1995. Comparison of imposex response in three Prosobanch species. Hydrobiologia., 309:29-35.

Kure, L. K. \& Depledge, M. H. 1994. Accumulation of organotin in Littorina littorea and Mya arenaria from Danish coastal waters. Environ. Pollut., 84: 149-157.

Matthiessen, P. \& Gibbs, P. E. 1998. Critical appraisal of the evidence for Tributyltin - mediated endocrine disruption in Mollusks. Environ. Toxicol. Chem.,17:37-43.

Morcillo, Y. \& Porte, C. 1998. Monitoring of organotin compounds and their effects in marine molluscs. Trends Anal. Chem., 17:109-116.

Oehlmann, J.; Stroben, E.; Schulte-Oehlmann, U.; Bauer, B.; Fioroni, P. \& Markert, B. 1996. Tributyltin biomonitoring using prosobranchs as sentinel organisms. Fresenius. J. Anal. Chem., 354:540-545.

Pelletier, E. \& Normandeau, C. 1997. Distribution of butyltin residues in mussels and sea stars of the St Lawrence estuary. Environ. Technol., 18:1203-1208.

Rudel, H. 2003. Case study: bioavailability of tin and tin compounds. Ecotoxicol. Environ. Safety, 56:180189.

Stroben, E.; Schulte-Oehlmann, U.; Fioroni, P. \& Oehlmann, J. 1995. A comparative method for easy assessment of coastal TBT pollution by the degree of imposex in prosobranch species. Haliotis, 24:1-12.

Takahashi, S.; Tanabe, S. \& Kubodera, T. 1997. Butyltin residues in deep-sea organisms collected from Suruga Bay, Japan. Environ. Sci. Technol., 31:3109.

Takahashi, S.; Lee, J. S.; Tanabe, S. \& Kubodera, T. 1998. Contamination and specific accumulation of organochlorine and butyltin compounds in deep-sea organisms collected from Suruga Bay, Japan. Sci. Total Environm., 214:49-64. 
Takahashi, S.; Tanabe, S.; Takeuchi, I. \& Miyazaki, N. 1999. Distribution and specific bioaccumulation of butyltin compounds in marine ecosystem. Archs environ. Contamin. Toxicol., 37:50-61.

Sources of Unpublished Material

Ribeiro-Ferreira, V. 2002 Avaliação do Potencial da Espécie Stramonita haemastoma (Kool, 1987) como indicador biológico de contaminação ambiental por compostos Organo-estânicos. M.Sc. Thesis. Rio de Janeiro, Universidade Federal Fluminense.

(Manuscript received 05 August 2005; revised 02 February 2006; accepted 03 March 2006) 